\title{
Organic matter sedimentation and resuspension in tilapia (Oreochromis niloticus) ponds during a production cycle
}

\author{
Ricardo Jiménez-Montealegre ${ }^{\mathrm{a}, *}$, Marc Verdegem ${ }^{\mathrm{b}}$, \\ Jorge E. Zamora ${ }^{\mathrm{a}}$, Johan Verreth ${ }^{\mathrm{b}}$ \\ a Escuela de Ciencias Biológicas, Universidad Nacional, PO Box 86-3000, Heredia, Costa Rica \\ b Fish Culture and Fisheries Group, Wageningen Institute of Animal Sciences, \\ Wageningen University and Research Center, PO Box 338, 6700 AH Wageningen, The Netherlands
}

Received 13 March 2001; accepted 9 October 2001

\begin{abstract}
The rates of sedimentation and resuspension of organic carbon and total nitrogen were measured in earthen fishponds, based on nutrient input, water quality parameters and fish size and biomass. Material collected in sediment traps and soil samples were analyzed for organic carbon, total nitrogen, iron and aluminum concentrations. A dilution analysis method was used to differentiate between sedimented and resuspended particles. The rates of sedimentation and resuspension estimated from total solids increased during the experiment, ranging from 49.8 to $218.1 \mathrm{~g} / \mathrm{m}^{2}$ per day in the case of sedimentation and from 39.2 to 160.0 $\mathrm{g} / \mathrm{m}^{2}$ per day in the case of resuspension. Although fish weight increased through time, the relative resuspension did not change significantly, ranging from 42 to $47 \%$ of the total collected material. Total solids sedimentation and resuspension rates were highly correlated $(P \leq 0.01)$ to fish weight and biomass, chlorophyll- $a$, total suspended solids, total feed input and Secchi disk visibility. (C) 2002 Elsevier Science B.V. All rights reserved.
\end{abstract}

Keywords: Fish pond sediment; Sedimentation rate; Resuspension rate; Total nitrogen; Organic carbon

* Corresponding author. Tel.: + 506-277-3329; fax: + 506-237-6427.

E-mail address: rjimenez@una.ac.cr (R. Jiménez-Montealegre). 


\section{Introduction}

In aquatic systems, the increase or decrease of organic matter in the sediments is the difference between the rate of in situ produced and allochtonous material that reaches the bottom before being mineralized, and the rate of organic matter mineralization in the sediment. The rate of sedimentation (deposition) of particulate matter is determined by the particle size, shape, density with respect to water density, and water viscosity (Jørgensen, 1989). In pond aquaculture, the allochtonous contribution is considerable due to the addition of feed and/or organic fertilizer. For fish ponds, Avnimelech et al. (1999) reported sedimentation rates of total nitrogen and organic carbon of $1-3 \mathrm{~g} / \mathrm{m}^{2}$ per day and $15-30 \mathrm{~g} / \mathrm{m}^{2}$ per day, respectively.

Settled particles can be resuspended. Organic matter decomposition in fishpond bottoms can lead to anoxic conditions, and resuspension would favor the aerobic decomposition of organic matter. Considering that the various biotic and abiotic reactions in sediment results in large concentration differences between the sediments and the overlying water (Boyd, 1995), resuspension would also increase the exchange rate of materials from sediment to water.

Resuspension has not been considered in most studies of organic matter accumulation and decomposition. Avnimelech and Wodka (1988) found that resuspended material accounted for $50 \%$ of the total sedimentation flux in an $8 \mathrm{~m}$ deep reservoir. In fishponds, resuspension of organic matter accounted for $60-90 \%$ of the total solids flux (Avnimelech et al., 1999). Scheffer (1998) reviewed and developed quantitative approaches to the assessment of resuspension in shallow lakes. Resuspension depends upon the sheer stress created by waves and currents on the pond bottom, the less consolidated soils being more sensitive (Lee, 1970; Kamp-Nielsen, 1989). This water turbulence also causes resuspension, transport and resettling of sediments at places with less stress (Peterson, 1999). The area and depth of the lake, and wind speed are very important factors in resuspension (Scheffer, 1998). Sediment resuspension by fish was important in lakes, with an approximate linear relationship between benthivorous fish biomass (carp or bream) and resuspension rate. The resuspension rate ( $\mathrm{kg}$ resuspended per day) was approximately five times the fish biomass (Breukelaar et al., 1994; Scheffer, 1998).

Of special interest in fishponds is the bio-turbulence created by benthivorous fish. Fish move actively while searching for food, causing water turbulence (Havens, 1991; Tátrai et al., 1997). When comparing the effect of fish on sedimentation and resuspension, the last is largely a fish-driven process, whereas sedimentation is a function of primary productivity. Direct measurements and factors that influence the rates of resuspension and sedimentation are scarce. Several studies have identified fish species, fish weight and/or fish biomass, to affect the resuspension rate in fish ponds (Tátrai et al., 1997; Avnimelech et al., 1999). The objectives of this study were to measure sedimentation and resuspension rates during a growing cycle of Oreochromis niloticus in ponds, and to identify and quantify the principal factors (e.g. feed input, fish weight and number, and water quality parameters) that contribute to resuspension or sedimentation. 


\section{Materials and methods}

An earthen fishpond of $800 \mathrm{~m}^{2}$ and $1 \mathrm{~m}$ depth was stocked with $87 \mathrm{~g}$ O. niloticus at 1.5 fish per $\mathrm{m}^{2}$. Pond was not artificially aereated during the experiment, had no vegetation over the banks, and the pond bottom was sandy. Fish were fed a $5 \mathrm{~mm}$ dry floating pellets with $30 \%$ crude protein, at $2 \%$ body weight per day at the beginning of the experiment, decreasing to $1.2 \%$ at the end of the experiment. The daily ration was divided into three equal portions applied at 07:00, 11:00 and 15:00 $\mathrm{h}$, broadcast as evenly as possible over the pond surface. After 50 days, feeding was stopped for 14 days to assess the effect of feeding on the parameters measured. Feeding was resumed after day 65.

Sedimentation was measured by placing sediment traps in the pond bottom. Starting on days 7 and 9, two sediment traps were placed $20 \mathrm{~m}$ apart at the pond bottom. The sediment traps were made from PVC pipe with a diameter of $7 \mathrm{~cm}$. Traps were placed firmly in the pond bottom and trap heights were approximately $30 \mathrm{~cm}$ with no difference between samplings. Depending on the amount of sample collected by the traps, traps were removed from the pond after $24-48 \mathrm{~h}$. Until day 77 , traps were replaced every 14 days. All the material collected was transferred to plastic bags. Soil immediately next to the trap was sampled with a $6 \mathrm{~cm}$ diameter soil corer.

Pond water was sampled on the same days the sediment traps were placed using a $10 \mathrm{~cm}$ diameter, $60 \mathrm{~cm}$ height sampling tube. Samples were collected from three locations (near the inlet, outlet and center) and thoroughly mixed before analysis. Chlorophyll- $a$ concentration (acetone extraction) and total suspended solids in unfiltered samples were determined (APHA, 1989). The water samples were filtered through a GF/C Whatman glass fiber filter and the filtrate analyzed for total alkalinity, $\mathrm{NO}_{3}-\mathrm{N}$ (cadmium reduction), $\mathrm{NO}_{2}-\mathrm{N}$ (diazotization) and TAN (phenate method) (APHA, 1989). During trap placement, net primary productivity (light/dark bottles) was measured at 20 and $50 \mathrm{~cm}$ below water level and the primary productivity values from both depths were averaged.

The top $2 \mathrm{~cm}$ layer of the soil cores and the material collected in traps was dried. The weight of the material collected was determined following drying at $60{ }^{\circ} \mathrm{C}$ to constant weight. Organic carbon in soil and collected material were determined potentiometrically following dichromate oxidation (Raveh and Avnimelech, 1972), total Kjeldahl nitrogen was also determined (AOAC, 1980). Fe and Al concentrations in the material collected in soil cores and trap material were determined using atomic absorption spectroscopy after acid digestion (Lim and Jackson, 1982).

Resuspended material can contribute to trap yield (Fig. 1), and measured sedimentation is the sum of the organic matter that settles from the water column plus the material that is resuspended from the bottom:

$$
\mathrm{ST}=\mathrm{Sed}+\mathrm{Res}
$$

where, ST is the total material trapped, Sed is the trapped material from sedimentation and Res is the trapped material from resuspension. The material sedimenting from the water is mainly organic, while resuspended material contains a larger 


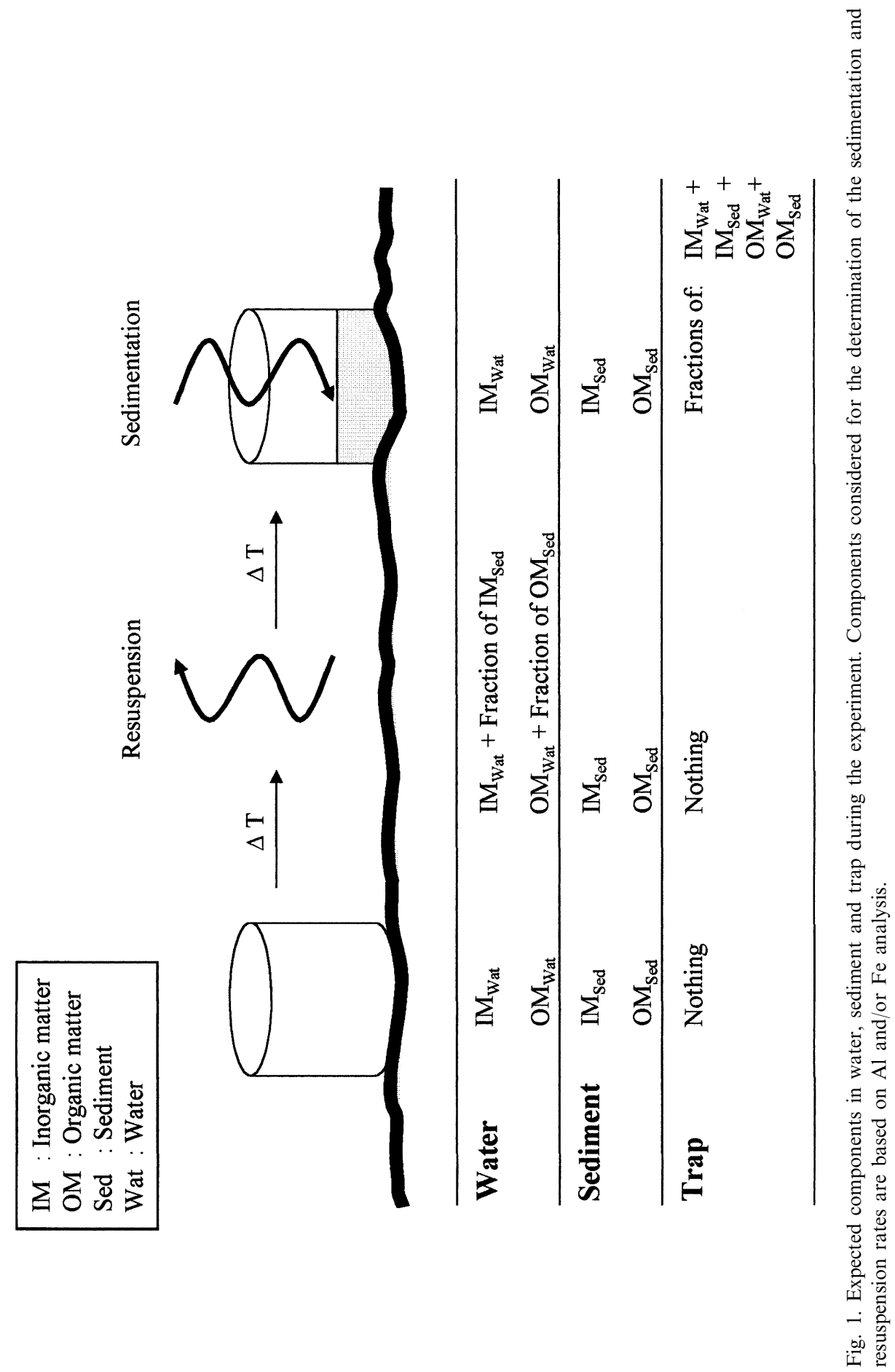


fraction of inorganic matter. The amount of organic matter caught in the trap equals:

$$
\mathrm{OM}_{\mathrm{T}}=\left(\frac{\mathrm{OM}}{\mathrm{Sed}}\right) \operatorname{Sed}+\left(\frac{\mathrm{OM}}{\mathrm{Res}}\right) \mathrm{Res}
$$

where, $\mathrm{OM}_{\mathrm{T}}$ is the total organic matter found in the trap, Sed and Res is the sedimented and resuspended fractions, $(\mathrm{OM} / \mathrm{Sed})$ represent the mass fraction of organic matter from sedimentation, and $(\mathrm{OM} / \mathrm{Res})$ is the mass fraction of organic matter in resuspended material. A similar equation can be written for the trapped inorganic material:

$$
\mathrm{IM}_{\mathrm{T}}=\left(\frac{\mathrm{IM}}{\mathrm{Sed}}\right) \operatorname{Sed}+\left(\frac{\mathrm{IM}}{\operatorname{Res}}\right) \operatorname{Res}
$$

where, $\mathrm{IM}_{\mathrm{T}}$ is the total inorganic matter found in the trap, and (IM/Sed) and (IM/Res) represent the mass fractions of inorganic matter in sedimented and resuspended material, respectively.

When organic and inorganic matter is considered, one method to distinguish between the sedimented and the resuspended material, is by comparison of the concentrations of tracers in seston, trap catch and the upper part of the sediment. This enables assessment of resuspension because the elemental composition of resuspended particles is different from particles originating in the water column. Avnimelech et al. (1999) proposed a dilution analysis to evaluate the magnitude of sedimentation and resuspension based on the assumption that resuspended material in most fishponds contains elements (Fe, Al, Si) abundant in the soil. The method assumes that these elements are at very low concentrations in particles originating in the water. The concentration of an element in the trap material collected is the weighted average of the concentration in sedimentation and resuspension fluxes. If the concentration of the relevant ions $(\mathrm{Fe}, \mathrm{Al}$ or $\mathrm{Si}$ ) in the resuspension flux is assumed to be identical to the composition of the upper layer of the pond bottom, and the concentration of that soil-derived element in the sedimentation flux is assumed to be zero, then total resuspension and sedimentation flux rates can be calculated (Avnimelech et al., 1999):

$$
\frac{W_{\mathrm{r}}}{W_{\mathrm{t}}}=\frac{C_{\mathrm{t}}}{C_{\mathrm{r}}}
$$

where, $W_{\mathrm{r}}$ is the dry weight of material collected from resuspension, $W_{\mathrm{t}}$ is the total mass collected in the trap, and $C_{\mathrm{t}}$ and $C_{\mathrm{r}}$ are the concentrations of $\mathrm{Fe}, \mathrm{Al}$ or $\mathrm{Si}$ in the material collected, and in the resuspension flux, respectively. This approach was followed in the present study. Sedimentation and resuspension rates were calculated for total solids, organic carbon and total nitrogen.

To assess the possible correlation between the sedimentation/resuspension rates and other parameters, a Pearson correlation matrix was constructed. The parameters included were chlorophyll- $a$ in the water column, Secchi disk visibility, fish weight and biomass, total feed offered, and water column suspended solids. 


\section{Results}

Tilapia grew from $86.6 \pm 17.9$ to $210.0 \pm 64.0 \mathrm{~g}$ in 77 days, realizing a specific growth rate of $1.15 \%$ body weight per day, and a feed conversion ratio of 1.75 over the culture period. The feed input at the beginning of the experiment was $3.24 \mathrm{~g} / \mathrm{m}^{2}$ per day, and reached $6.19 \mathrm{~g} / \mathrm{m}^{2}$ per day on day 77 . The overall fish biomass reached $2729 \mathrm{~kg} / \mathrm{ha}$ and the total mortality was $13 \%$. Both water suspended solids and chlorophyll- $a$ increased steadily until day 63, and decreased drastically between day 63 and 65, indicating that an algae die-off occurred during that time interval (Fig. 2 ). On day 77, water suspended solids and chlorophyll- $a$ concentrations increased again.

The rate of material collected (dry basis) increased from $88.5 \pm 7.1 \mathrm{~g} / \mathrm{m}^{2}$ per day (first week) to $330.7 \mathrm{~g} / \mathrm{m}^{2}$ per day before day 50 when feeding was stopped. After feeding was stopped, the total amount of material collected in the traps decreased. Between day 63 and 65, the deposition rate increased to the highest value during the experiment $\left(377.7 \pm 21.0 \mathrm{~g} / \mathrm{m}^{2}\right.$ per day), coinciding with the algae die-off.

The mean concentrations of organic $\mathrm{C}$ and total $\mathrm{N}, \mathrm{Fe}$ and $\mathrm{Al}$, both in soil and material collected are presented in Fig. 3. In soil samples, organic carbon was nine to ten times higher than total nitrogen (calculated on the basis of molar concentrations) representing an average $\mathrm{C}: \mathrm{N}$ ratio of $9.8 \pm 1.5$ (mean \pm S.D.) for the whole experiment. A similar $\mathrm{C}: \mathrm{N}$ ratio was found in the trapped material $(9.7 \pm 1.8)$. The concentrations of organic $\mathrm{C}$ and total $\mathrm{N}$ in the trapped material were on average 8 times higher than in the upper $2 \mathrm{~cm}$ sediment layer (Figs. 3 and 4).

The use of either $\mathrm{Fe}$ or $\mathrm{Al}$ as tracers yielded similar results $(P>0.05)$, so the obtained values were averaged. The sedimentation rate of total solids, organic $\mathrm{C}$ and total $\mathrm{N}$ and based on the $\mathrm{Fe}$ and $\mathrm{Al}$ concentration differences between trapped material and the top $2 \mathrm{~cm}$ sediment layer were calculated (Eq. (3)). At the beginning of the experiment, total solids sedimentation rate was about $50 \mathrm{~g} / \mathrm{m}^{2}$ per day and

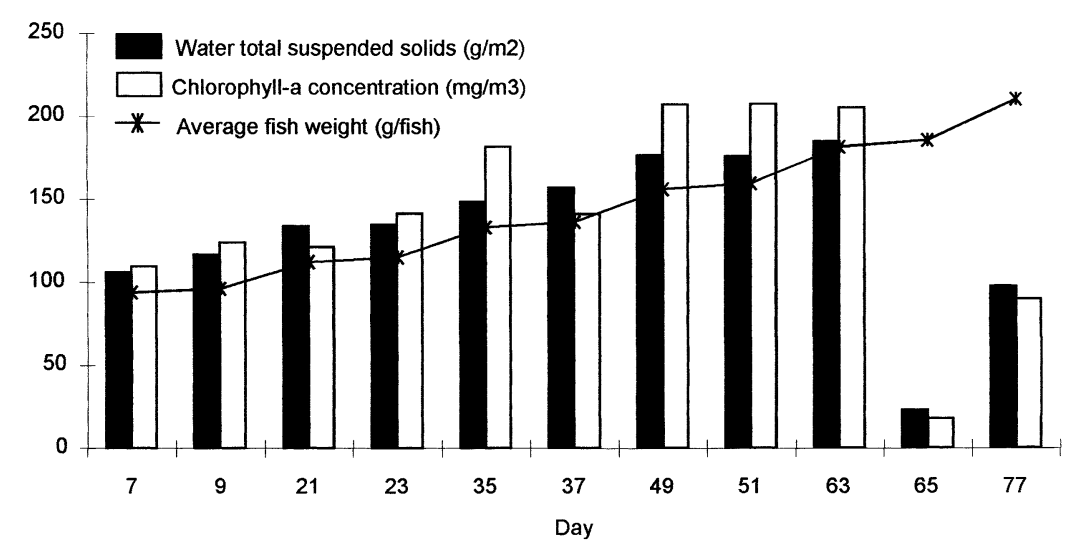

Fig. 2. Relation between average fish weight, water total suspended solids and chlorophyll- $a$ concentration. Feeding was stopped on day 51 and resumed on day 65. 

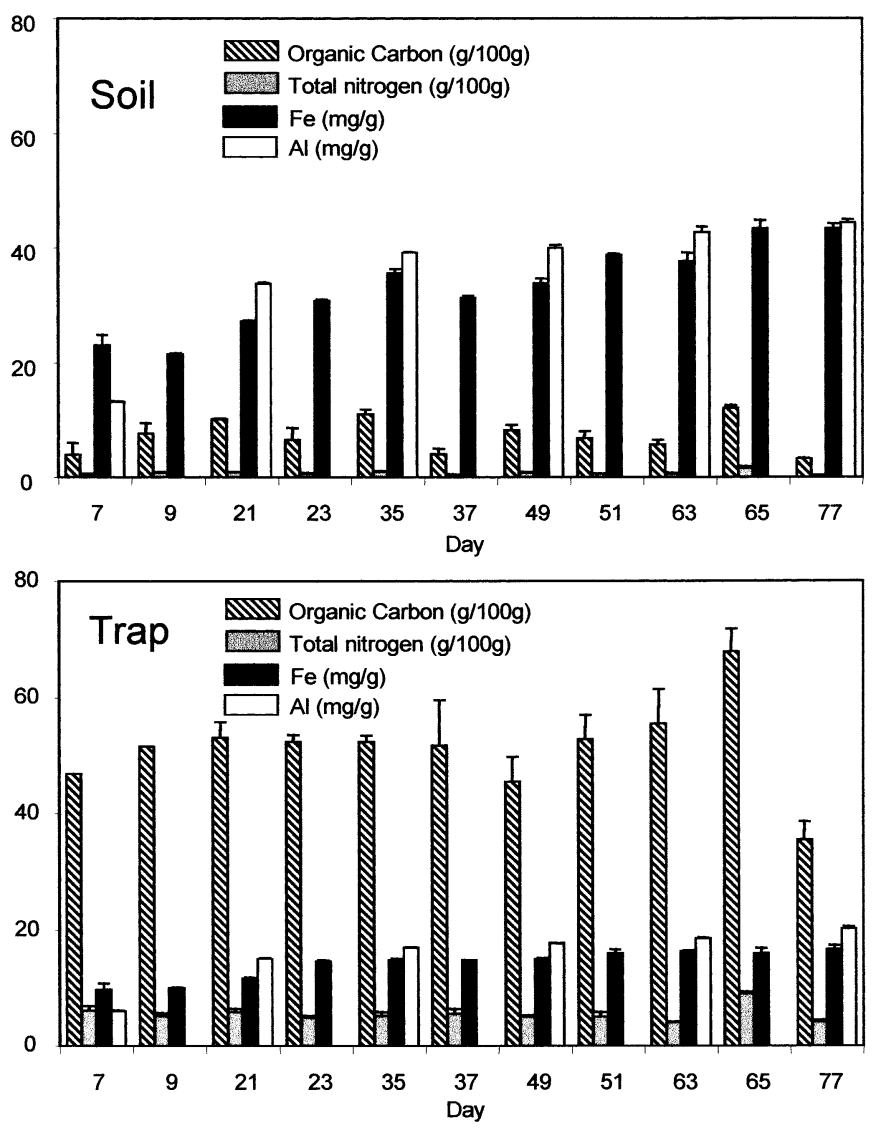

Fig. 3. Mean concentration ( \pm S.D., $n=3$ ) of organic carbon, total nitrogen, iron and aluminum in soil and collected material (dry basis). Feeding was stopped on day 51 and resumed on day 65 .

increased almost by three times over 6 weeks. After day 50, the rate decreased, increasing again when feeding was resumed. Organic carbon and total nitrogen had the same pattern as total solids. The fluxes of organic C were $25-90 \mathrm{~g} / \mathrm{m}^{2}$ per day and for total $\mathrm{N}$ were 3-9 $\mathrm{g} / \mathrm{m}^{2}$ per day. Only on day 65 were the sedimentation rates higher, due to the algal die-off. The percentage of sedimented material in the trapped material ranged between 50 and $60 \%$ during the whole experiment. The rates of resuspension of total solids, organic carbon and total nitrogen, and the percentage of resuspended matter collected in the trapped material are presented in Fig. 5. Resuspension accounted for $40-50 \%$ of the material collected in the traps. When feeding was stopped, both sedimentation and resuspension rates decreased.

Total solids sedimentation and resuspension rate were highly correlated $(P \leq$ 0.01 ) with fish weight and biomass, chlorophyll- $a$, total suspended solids, total feed and Secchi disk visibility (Table 1). 


\section{Discussion}

The values for the sedimentation rate for organic carbon and total nitrogen (but not for total solids) are comparable to other reports for similar fish size. In Avnimelech et al. (1999) increased fish size and increased nutrient input, as time progressed, were positively correlated to increased sedimentation rate. Both the fish weight increase and the increased feed input led to higher suspended solids in the water column. The characteristics of pond management (e.g. feed input) are important to consider when reporting sedimentation rates because the sedimentation found in this experiment was two to three times higher after 50 days. Although fish weight increased over time, the resuspension did not change significantly during the experiment, and was always between 42 and $47 \%$ of the total collected material, irrespective of the component measured (total solids, organic carbon or total nitrogen). The constant resuspension can be explained by the fact that, during the experiment, the primary productivity (so the phytoplankton biomass) and the feed input increased at the same time as the fish increased its weight (see Fig. 2). Resuspension rate can be related to the fish weight and the number of fish and not the fish biomass only. Fish weight (and number) can not be related to the percentage of resuspension without reference to the total amount of material collected in traps. Therefore, the use of absolute values is more meaningful.

The C:N ratio of the sediment was comparable to the $\mathrm{C}: \mathrm{N}$ ratio of the material collected. When organic matter is mineralized, nitrogen is used faster than carbon and the resultant material is characterized by a lower carbon to nitrogen ratio (Nixon and Pilson, 1983). Hamilton and Mitchell (1997) mentioned that particle settling velocities could be in the order of $1 \mathrm{~mm} / \mathrm{s}$. Considering the trap height of $30 \mathrm{~cm}$, the total water column residence time would be $300 \mathrm{~s}$, a limited time for slow chemical reactions such as microbial degradation to occur (Avnimelech et al.,

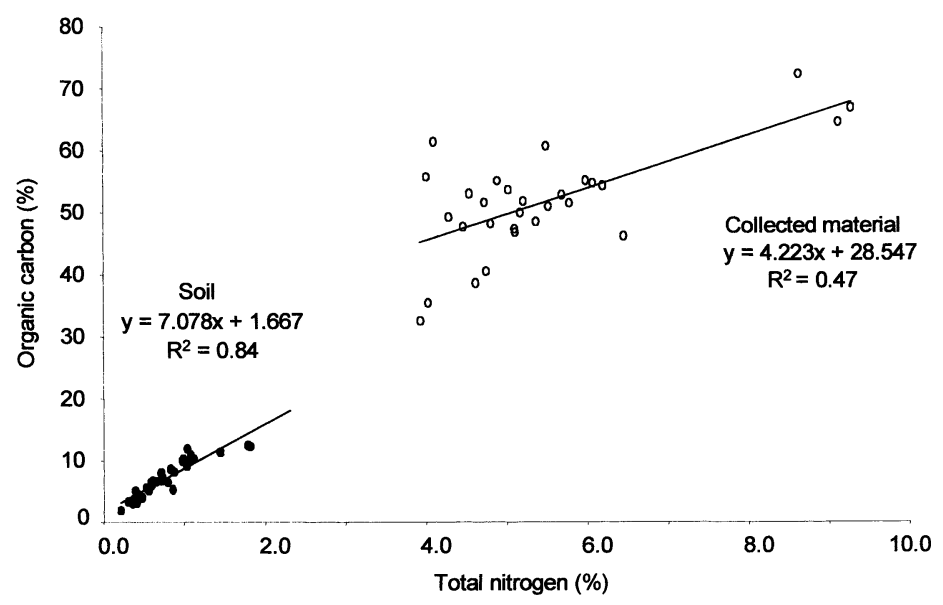

Fig. 4. Relation between total nitrogen and organic carbon in soil and collected material. 

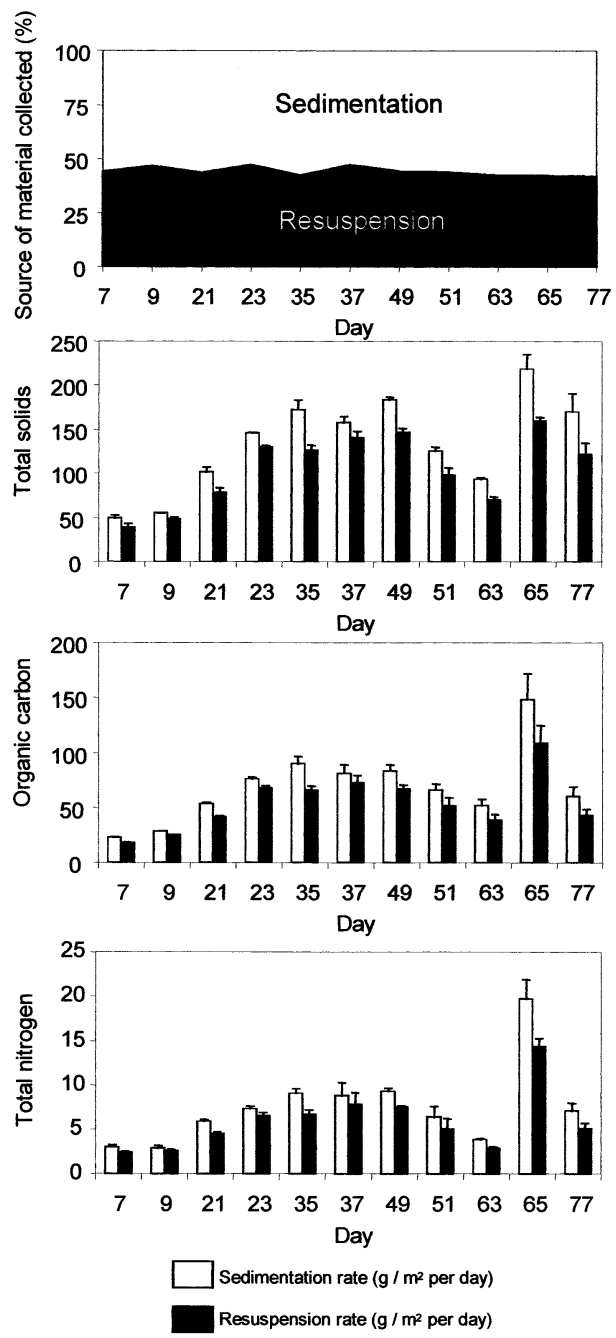

Fig. 5. Source of material collected ( $\%$ of total collected), sedimentation and resuspension rates, estimated from total solids, organic carbon and total nitrogen. Feeding was stopped on day 51 and resumed on day 65. Determinations based on iron and aluminum concentrations in the soil and the material collected were not different $(P>0.05)$ and were averaged (mean \pm S.D., $n=6$ ).

1999). The similarity in the $\mathrm{C}: \mathrm{N}$ ratios of both the sediment and the material collected confirms this. Carbon and nitrogen concentrations in the trapped material were on average eight times higher than the concentrations found in the upper $2 \mathrm{~cm}$ of sediment. Most likely, relatively more organic carbon was resuspended than inorganic soil particles.

The use of $\mathrm{Al}$ or $\mathrm{Fe}$ as tracers for estimating resuspension gave similar results, and the use of one tracer is sufficient for future studies. The amount of material 
collected in the traps ranged between 90 and $400 \mathrm{~g} / \mathrm{m}^{2}$ per day. Avnimelech et al. (1999) reported flux rates of 622 and $1331 \mathrm{~g} / \mathrm{m}^{2}$ per day for two ponds stocked with similar sized tilapias at a comparable density. Breukelaar et al. (1994) reported a resuspension rate equaling about five times the fish biomass per $\mathrm{m}^{2}$ per day, which is also greater than our values. One possible explanation is the characteristic of the pond bottom. The dilution analysis used to evaluate the sedimentation and resuspension based on $\mathrm{Al}$ or $\mathrm{Fe}$ as tracers assumes that the density of soil and organic particles are similar, and are resuspended in the same proportion. Resuspended material was most likely organic matter with a low density, while the inorganic soil was hardly resuspended, because the material was sandy, so the size and density of the particles was too large to be lifted higher than $30 \mathrm{~cm}$ into the water column. The fact that the pond soil was sandy supports this result. It is expected that if the pond bottom is muddy, containing more clay minerals and less sand or silt the resuspension rate would be higher. Although the studies by Avnimelech et al. (1999) reported higher resuspension rates, the important question is how much organic matter was resuspended, as this drives the food web in the pond. In this study, $45-68 \%$ of the trapped material was carbon.

For the evaluation of sedimentation and resuspension rates, the pause of fish feeding had an important consequence. The introduction of organic matter and nutrients into the pond ceased, and dissolved nutrients in the water column decreased to a level that could limit the phytoplankton growth (Diana et al., 1991; Knud-Hansen et al., 1991). Moreover, the exhaustion of nutrients could cause phytoplankton populations to collapse (Boyd, 1990). Resuspension can be caused by bio-turbulence either by fish foraging at the pond bottom when artificial feeding was suspended, or by fish moving actively during feeding. With the experimental design it was not possible to distinguish the relative importance of these sources of sediment resuspension. According to Havens (1991) if no feed is applied less turbulence is caused and less resuspension is expected. Following data of Fig. 5, it seems that fish always searched in the sediments, inducing less disturbance when

Table 1

Two-tailed Pearson correlation matrix based on seven sampling periods (days 7-49; significant correlation, $P \leq 0.01$ )

\begin{tabular}{|c|c|c|c|c|c|c|c|}
\hline & TSSR & TSRR & CHL-A & SD & FW & FB & $\mathrm{TF}$ \\
\hline $\begin{array}{l}\text { Sedimentation rate, total solids } \\
\text { (TSSR) }\end{array}$ & - & & & & & & \\
\hline $\begin{array}{l}\text { Resuspension rate, total solids } \\
\text { (TSRR) }\end{array}$ & 0.98 & - & & & & & \\
\hline $\begin{array}{l}\text { Chlorophyll- } a \text { concentration } \\
\text { (CHL-A) }\end{array}$ & 0.86 & 0.84 & - & & & & \\
\hline Secchi depth (SD) & -0.79 & -0.77 & -0.90 & - & & & \\
\hline Fish weight (FW) & 0.78 & 0.73 & 0.97 & -0.83 & - & & \\
\hline Fish biomass (FB) & 0.79 & 0.74 & 0.97 & -0.83 & 1.00 & - & \\
\hline Total feed (TF) & 0.80 & 0.75 & 0.97 & -0.83 & 1.00 & 1.00 & - \\
\hline Water suspended solids & 0.80 & 0.76 & 0.97 & -0.86 & 0.99 & 0.99 & 0.99 \\
\hline
\end{tabular}


feed was not offered. Resuspension (absolute and relative values) decreased during feed cessation, although not significantly.

With increasing feed input, the concentration of suspended solids (including phytoplankton) and inorganic dissolved nutrients (ammonium, nitrate, nitrate) in the water column increased (data not shown). When feeding was stopped, the phytoplankton density (expressed as chlorophyll- $a$ concentration) remained constant at $205-208 \mathrm{mg} / \mathrm{m}^{3}$ up to day 63 . This was followed by a sudden die-off of phytoplankton, and on day 65 the chlorophyll- $a$ concentration dropped to 18 $\mathrm{mg} / \mathrm{m}^{3}$. Studies on phytoplankton populations have not led to conclusive results that explain phytoplankton dynamics in fishponds (Sevrin-Reyssac, 1997). In this study too, it was not possible to identify the cause(s) of this die-off.

The dilution analysis to evaluate the magnitude of sedimentation and resuspension based on $\mathrm{Al}$ or $\mathrm{Fe}$ as tracers assumes that soil particles and organic particles have similar density and are resuspended in the same proportion. This is not always the case, as discussed here. What is important in estimating sedimentation and resuspension fluxes in fishponds is to evaluate the dynamics of the organic matter that accumulates in the pond bottom, and the effect of those processes on the mobilization of inorganic nitrogen or phosphorus.

\section{Acknowledgements}

This study was partly financed by the European Commission under the INCODC program (Contract No. IC18-CT97-0202), and partly financed by the 'Programa UNA-LUW/Ciencias Acuáticas', a Cooperation Project between the Escuela de Ciencias Biológicas, Universidad Nacional, Heredia, Costa Rica, and the Fish Culture and Fisheries Group of the Wageningen University and Research Center, The Netherlands. Professor Dr E. A. Huisman and Professor Dr Y. Avnimelech are thanked for their valuable comments and suggestions.

\section{References}

Association of Official Analytical Chemists (AOAC), 1980. Official methods of analysis. Association of Official Analytical Chemists, Inc., Arlington, Virginia, USA.

American Public Health Association (APHA), American Water Works Association, and Water Pollution Control Federation), 1989. Standard methods for the examination of water and wastewater, $18 \mathrm{th}$ ed. American Public Health Association, New York, USA.

Avnimelech, Y., Wodka, M., 1988. Accumulation of nutrients in the sediments of Maaleh Kishon reclaimed effluents reservoirs. Water Res. 22, 1437-1442.

Avnimelech, Y., Kochva, M., Hargreaves, J.A., 1999. Sedimentation and resuspension in earthen fish ponds. J. World Aquacult. Soc. 30, 401-409.

Breukelaar, A.W., Lammens, E.H.R.R., Breteler, J.G.P.K., Tátrai, I., 1994. Effects of benthivorous bream (Abramis brama) and carp (Cyprinus carpio) on sediment resuspension and concentrations of nutrients and chlorophyll- $a$. Freshwater Biol. 32, 113-121.

Boyd, C.E., 1990. Water Quality in Ponds for Aquaculture. Birmingham Publishing, Birmingham, AL. Boyd, C.E., 1995. Bottom Soils, Sediment, and Pond Aquaculture. Chapman \& Hall, NY, USA. 
Diana, J.S., Lin, C.K., Schneeberger, P.J., 1991. Relationships among nutrient inputs, water nutrient concentrations, primary production, and yield of Oreochromis niloticus in ponds. Aquaculture 92, $323-342$.

Hamilton, D.P., Mitchell, S.F., 1997. Wave-induced shear stress, plant nutrients and chlorophyll in seven shallow lakes. Freshwater Biol. 38, 159-168.

Havens, K.E., 1991. Fish-induced sediment resuspension: effects on phytoplankton biomass and community structure in a shallow hypereutrophic lake. J. Plankton Res. 13, 1163-1176.

Jørgensen, E., 1989. Sedimentation. In: Jørgensen, S.E., Gromiec, M.J. (Eds.), Mathematical Submodels in Water Quality Systems. Developments in Environmental Modelling, vol. 14. Elsevier, Amsterdam, pp. $109-124$.

Kamp-Nielsen, L., 1989. Sediment-water exchange models. In: Jørgensen, S.E., Gromiec, M.J. (Eds.), Mathematical Submodels in Water Quality Systems. Developments in Environmental Modelling, vol. 14. Elsevier, Amsterdam, pp. 371-398.

Knud-Hansen, C.F., Batterson, T.R., McNabb, C.D., Harahat, I.S., Sumantadinata, K., Eidman, H.M., 1991. Nitrogen input, primary productivity and fish yield in fertilized freshwater ponds in Indonesia. Aquaculture 94, 49-63.

Lee, G.F., 1970. Factors Affecting the Transfer of Materials Between Water and Sediments. Eutrophication Information Program. Literature Rev. 1. University of Winsconsin, Madison.

Lim, C.H., Jackson, M.C., 1982. Dissolution for total elements analysis. In: Page, A.L., Miller, R.H., Keeney, D.R. (Eds.), Methods of soil analysis. Part 2: Chemical and Microbiological Properties. Am Soc Agronom Inc/Soil Sci Am Inc Publ, Winsconsin/Madison, pp. 1-12.

Nixon, S.W., Pilson, E.Q., 1983. Nitrogen in estuarine and coastal marine ecosystems. In: Carpenter, E.J., Capone, D.G. (Eds.), Nitrogen in the Marine Environment. Academic Press, New York, pp. $598-612$.

Peterson, E.L., 1999. Benthic shear stress and sediment condition. Aquacult. Eng. 21, 85-111.

Raveh, A., Avnimelech, Y., 1972. Potentiometric determination of soil organic matter. Soil Sci. Soc. Am. Proc. 36, 967-968.

Scheffer, M., 1998. Ecology of Shallow Lakes. Chapman and Hall, London, UK.

Sevrin-Reyssac, J., 1997. L'instabilite du phytoplancton et le phenomene des eaux claires dans les etangs de pisciculture. Environ. Exp. Bot. 38, 211-221.

Tátrai, I., Oláh, J., Paulovits, G., Mátýas, K., Kawiecka, B.J., Józsa, V., Pekár, F., 1997. Biomass dependent interactions in pond ecosystems: responses of lower trophic levels to fish manipulation. Hydrobiologia 345, 117-129. 